\title{
Virulence profile and genetic variability of Staphylococcus aureus isolated from artisanal cheese
}

\author{
M. A. Ferreira, ${ }^{*}$ L. G. Bernardo, ${ }^{*}$ L. S. Neves, $†$ M. R. H. Campos, ${ }^{*}$ J. Lamaro-Cardoso, $\dagger$ and M. C. P. André ${ }^{1}$ \\ ${ }^{*}$ Faculty of Nutrition, and \\ †Tropical Pathology and Public Health Institute, Federal University of Goiás, Goiânia 74605-050, Brazil
}

\begin{abstract}
The objectives of this study were to characterize Staphylococcus aureus isolated from artisanal and industrialized Minas frescal cheeses, to determine their antimicrobial susceptibility profile as well as the genetic similarity among the isolates. The isolates were also tested for staphylococcal enterotoxin genes and other virulence factors. Fifty-six artisanal raw milk cheeses sold at street fairs and 10 industrialized cheeses commercialized in supermarkets of Goiânia, Goiás, were analyzed. Staphylococcus aureus was confirmed in 19 samples $(33.9 \%)$ of artisanal cheese by detection of femA gene, in which 29 isolates were obtained. These isolates were submitted to the antimicrobial susceptibility test and classified into 9 different profiles (A-I). Thirteen isolates (44.8) were resistant to penicillin and 3 (10.3) to tetracycline, with 2 (7.4) resistant to both. The multiplex PCR technique was performed to detect virulence genes that code for the production of hemolysins (Hla and Hlb), toxic shock syndrome toxin (TSST-1), exfoliative toxins (ETa and ETb), and staphylococcal enterotoxins [SE; SEA-SEE, SEG-SEJ, SEM-SEO]. All the isolates amplified for the hla gene and $14(48.3 \%)$ for the hlb gene. The seh gene was the most frequently detected $(\mathrm{n}=11,37.9 \%)$, followed by seo gene $(\mathrm{n}=3 ; 10.3 \%)$. In one isolate $(3.4 \%), 4$ enterotoxins genes were detected, and in another, $6(3.4 \%)$ were detected. The comparison performed by pulsedfield gel electrophoresis of the 29 isolates revealed 18 genotypic profiles, which were grouped into 5 clusters. The genotyping found high genetic similarity among the isolates. Identical isolates were obtained from different samples and one sample showed more than one genetically different isolate. The high prevalence of $S$. aureus in the Minas Frescal cheese samples, as well as the detection of toxin encoding genes identified in this study, warns of the necessity to reduce the contamina-
\end{abstract}

Received December 8, 2015.

Accepted February 29, 2016.

${ }^{1}$ Corresponding author: mcporfirio@hotmail.com tion levels in this type of cheese through monitoring and controlling the production and trade of the product.

Key words: Staphylococcus aureus, cheese, antimicrobial resistance, staphylococcal enterotoxin

\section{INTRODUCTION}

Staphylococcus aureus is one of the most important human and animal pathogens. It has a broad set of virulence mechanisms associated with infectivity, production of toxins, and antimicrobial resistance (Argudin et al., 2010).

Some strains of $S$. aureus can produce toxins that are members of the pyrogenic toxin superantigen family, such as the staphylococcal toxic shock syndrome toxin (TSST-1), which is responsible for generating an immune hyper-response in the host and has already been detected in $S$. aureus isolated from foods (Cha et al., 2007). These bacteria can produce exfoliative toxins, which promote the cleavage of the skin extract, causing severe cutaneous syndromes (Zschöck et al., 2005). Most strains secrete enzymes and cytotoxins that include coagulase and 4 hemolysins $(\alpha, \beta$, gamma, and delta). Alpha and $\beta$ hemolysins (Hla and Hlb) are dermonecrotic and neurotoxic, turn off the immune system by direct cytotoxic effect, and degrade soft tissues (Vandenesch et al., 2012).

Among the toxins produced by $S$. aureus, staphylococcal enterotoxins are a concern, because when produced in foods staphylococcal enterotoxins can cause food poisoning, which is one of the most prevalent foodborne diseases around the world (ECDC, 2015). These toxins present emetic activity and are called classic staphylococcal enterotoxins (SE; SEA-SEE), which occur more frequently in cases and outbreaks of food poisoning, along with other more recently identified (SEG, SEH, SEI, SER, and SET (Wallin-Carlquist et al., 2010; Xu and McCormick, 2012). In addition to these, other enterotoxins called staphylococcal enterotoxin-like proteins $(\mathbf{S E} \boldsymbol{l})$ include $\mathrm{SE} l \mathrm{~J}, \mathrm{~K}, \mathrm{~L}, \mathrm{M}, \mathrm{N}, \mathrm{O}, \mathrm{P}, \mathrm{Q}, \mathrm{S}, \mathrm{U}$, and V. Although the SEl toxins are homologous and structurally similar to the staphylococcal enterotoxins, 
emesis activity has not yet been confirmed in humans (Xu and McCormick, 2012).

Staphylococcus aureus was the second most common pathogen responsible for foodborne diseases in Brazil between 2000 and 2014. Milk and its derivatives were among the foods most frequently involved in outbreaks of foodborne diseases (ANVISA, 2015).

Minas frescal cheese is one of the most consumed cheeses in Brazil and has high susceptibility to microbiological and proteolytic changes due to its high moisture content and handling (Chalita et al., 2009). According to Brazilian law, this type of cheese must be produced in the dairy industry with pasteurized milk. However, this food is also manufactured from raw milk and marketed in the informal sector, without regulation or sanitary supervision. For these reasons, it is frequently involved in the transmission of pathogenic bacteria and staphylococcal food poisoning outbreaks (Dorigon, 2010).

Additionally, bacteria isolated from foods of animal origin may show resistance to several antimicrobial agents used to treat diseases, which may influence the effectiveness for treatment (Delsol et al., 2010; Araújo et al., 2011).

The aims of the study were to (1) evaluate the prevalence of $S$. aureus in artisanal and industrialized Minas frescal cheese sold in the municipality of Goiânia, Brazil; (2) determine the antimicrobial susceptibility profile of the isolates; (3) molecularly characterize the isolates for the presence of virulence genes and genetic similarity by macrorestriction analysis using pulsedfield gel electrophoresis (PFGE).

\section{MATERIALS AND METHODS}

\section{Cheese Sampling}

In this study, 56 artisanal and 10 industrialized samples of Minas frescal cheese were purchased from retail sale sites along the market streets and from supermarkets, respectively, in the municipality of Goiânia, Goiás, Brazil, from June to August 2012. All samples were immediately transported to the laboratory in a refrigerated box $\left(4\right.$ to $\left.8^{\circ} \mathrm{C}\right)$ and kept at $4^{\circ} \mathrm{C}$ until analysis.

\section{Isolation of Coagulase-Positive Staphylococci}

To enumerate coagulase-positive staphylococci (CPS), the samples were processed by surface plating on Baird-Parker agar with egg yolk tellurite emulsion and incubated at $37^{\circ} \mathrm{C}$ for $48 \mathrm{~h}$ under aerobic conditions. Up to 5 typical or atypical (or both) presumptive colonies were selected and tested using standard micro- biological procedures such as Gram staining, catalase, and thermostable nuclease detection. The coagulase production was performed by tube test using rabbit serum (Bennett and Lancette, 2001). A pure culture of each isolate was kept frozen at $-80^{\circ} \mathrm{C}$ for further analysis.

\section{Antimicrobial Susceptibility Test-Disk Diffusion Method}

All CPS isolates were subjected to an antimicrobial susceptibility test by the disc diffusion method on Müeller Hinton agar (CLSI, 2015). Penicillin (10 UI), cefoxitin $(30 \mu \mathrm{g})$, trimethoprim/sulfamethoxazole $(1.25 / 23.75 \mu \mathrm{g})$, rifampin $(5 \mu \mathrm{g})$, ciprofloxacin $(5 \mu \mathrm{g})$, tetracycline $(30 \mu \mathrm{g})$, erythromycin $(15 \mu \mathrm{g})$, quinupristin/dalfopristin $(15 \mu \mathrm{g})$, and clindamycin $(2 \mu \mathrm{g})$ were used as antimicrobial agents. Staphylococcus aureus ATCC 25923 was used as a reference strain for antimicrobial susceptibility testing.

\section{DNA Extraction}

The DNA extraction procedure was performed according to Aires-de-Sousa et al. (2007). The pure culture was thawed and streaked onto Tryptone Soya Agar culture and incubated at $35^{\circ} \mathrm{C}$ for 18 to $24 \mathrm{~h}$. Three to 4 colonies were suspended in $50 \mu \mathrm{L}$ of TE $1 \times$ buffer $(10 \mathrm{~m} M$ Tris, $1 \mathrm{~m} M$ EDTA, pH 8.0) with $1 \mu \mathrm{L}$ of lysostaphin $(10 \mathrm{mg} / \mathrm{mL})$ and incubated at $37^{\circ} \mathrm{C}$. After $30 \mathrm{~min}$, cell suspensions were placed in a boiling-water bath at $95^{\circ} \mathrm{C}$ for $15 \mathrm{~min}$. Then, $150 \mu \mathrm{L}$ of Milli-Q water was added and the solution was centrifuged $(13,000 \times$ $g$ ) for $5 \mathrm{~min}$ at $4^{\circ} \mathrm{C}$. The resulting supernatants were used as DNA templates in the PCR reactions.

\section{Identification of Staphylococcus aureus}

The CPS isolates were screened by PCR for the presence of the femA gene, which is specific for $S$. aureus, according to Mehrotra et al. (2000). The primers used for gene amplification were femA-F: 5'AAAAAAGCACATAACAAGCG $3^{\prime}$ and femA-R: $5^{\prime}$ GATAAAGAAGAAACCAGCAG $3^{\prime}$, to obtain a 132 bp amplicon.

The PCR reaction was performed in a reaction mixture with a final volume of $50 \mu \mathrm{L}$ containing $10 \mu \mathrm{L}$ of $5 \times$ reaction buffer $[20 \mathrm{mM}$ Tris- $\mathrm{HCl}(\mathrm{pH} 8.4), 50$ $\mathrm{m} M \mathrm{KCl}], 1.5 \mathrm{mM} \mathrm{MgCl}{ }_{2}, 100 \mu M$ of each dNTP, 0.2 $\mathrm{m} M$ of femA primers, $2.5 \mathrm{U}$ of Taq polymerase, and 20 ng of template DNA. The volume of this mixture was adjusted to $50 \mu \mathrm{L}$ with sterile deionized water. As positive controls, PCR reactions were carried out in paral- 
lel and contained template DNA extracted from the standard strains of $S$. aureus ATCC 25923. The PCR was performed under the following conditions: initial denaturation at $94^{\circ} \mathrm{C}$ for 5 min, subsequently followed by 35 cycles at $94^{\circ} \mathrm{C}$ for $2 \mathrm{~min}, 57^{\circ} \mathrm{C}$ for $2 \mathrm{~min}$, and $72^{\circ} \mathrm{C}$ for $1 \mathrm{~min}$, with a final extension of $7 \mathrm{~min}$ at $72^{\circ} \mathrm{C}$. The amplified products were detected by electrophoresis on $1.5 \%$ gel agarose containing ethidium bromide $(0.5 \mu \mathrm{g} /$ $\mathrm{mL})$. The electrophoresis was carried out at $100 \mathrm{~V}$ for $1 \mathrm{~h}$. The PCR products were visually examined and photographed under UV illumination.

\section{Detection of Virulence Genes}

The multiplex PCR technique was performed on all $S$. aureus isolates to detect virulence genes that code for the production of hemolysins (Hla and Hlb), TSST1, exfoliative toxins (ETa and ETb), and enterotoxins (SEA-SEE, SEG-SEJ, SEM-SEO), through 4 sequential reactions, according to Jarraud et al. (2002) and Holtfreter et al. (2007) with modifications. All the primer pairs used in this study and the multiplex reactions are listed in Table 1.

The PCR reactions were performed in a total volume of $25 \mu \mathrm{L}$ containing reaction buffer $(5 \times ; 10 \mathrm{~m} M$ Tris$\mathrm{HCl}, \mathrm{pH} 7.5,1 \mathrm{~m} M$ EDTA, pH 8.0), $5.0 \mathrm{~m} M \mathrm{MgCl}_{2}$, $100 \mathrm{~m} M$ of dNTP, 150 to $400 \mathrm{n} M$ of each primer, 1.0 $\mathrm{U}$ of Taq DNA polymerase, and 10 to $20 \mathrm{ng}$ of DNA template.

The PCR samples were subjected to amplification using a thermocycler (Axygen, Tewksbury, MA) according to the following program: initial denaturation at $95^{\circ} \mathrm{C}$ for $15 \mathrm{~min}$, followed by 35 cycles of denaturation at $95^{\circ} \mathrm{C}$ for $30 \mathrm{~s}$, annealing at $56^{\circ} \mathrm{C}$ for $30 \mathrm{~s}, 72^{\circ} \mathrm{C}$ for 50 $\mathrm{s}$, and a final extension at $72^{\circ} \mathrm{C}$ for $10 \mathrm{~min}$. Amplicons were separated by $1.5 \%$ agarose gel electrophoresis in $1 \times$ Tris-borate-EDTA (TBE) at $100 \mathrm{~V}$ for $90 \mathrm{~min}$ and viewed under Gel Doc XR UV transilluminator (Bio-Rad Laboratories, Hercules, CA). The gel images were analyzed with the QuantityOne software (BioRad Laboratories) after ethidium bromide $(0.5 \mu \mathrm{g} / \mathrm{mL})$ staining.

Table 1. Primers used in multiplex PCR reactions for virulence gene detection ${ }^{1}$

\begin{tabular}{|c|c|c|c|}
\hline Primer $^{2}$ & Sequence $\left(5^{\prime}-3^{\prime}\right)$ & bp & Reaction \\
\hline TSST F & TTCACTATTTGTAAAAGTGTCAGACCCACT & 180 & I \\
\hline TSST R & TACTAATGAATTTTTTTATCGTAAGCCCTT & & \\
\hline SEC F & GTAAAGTTACAGGTGGCAAAACTTG & 297 & \\
\hline SEC R & CATATCATACCAAAAAGTATTGCCGT & & \\
\hline SEB F & ATTCTATTAAGGACACTAAGTTAGGGA & 404 & \\
\hline SEB R & ATCCCGTTTCATAAGGCGAGT & & \\
\hline SEI F & CTCAAGGTGATATTGGTGTAGG & 576 & \\
\hline SEI R & AAAAAACTTACAGGCAGTCCATCTC & & \\
\hline SEO F & AGTTTGTGTAAGAAGTCAAGTGTAGA & 180 & II \\
\hline SEO R & ATCTTTAAATTCAGCAGATATTCCATCTAAC & & \\
\hline SEJ F & TAACCTCAGACATATATACTTCTTAACG & 300 & \\
\hline SEJ R & AGTATCATAAAGTTGATTGTTTTCATGCAG & & \\
\hline SEE $\mathrm{F}$ & CAAAGAAATGCTTTAAGCAATCTTAGGC & 482 & \\
\hline SEE $\mathrm{R}$ & CACCTTACCGCCAAAGCTG & & \\
\hline ETB F & CAGATAAAGAGCTTTATACACACATTAC & 612 & \\
\hline ETB R & AGTGAACTTATCTTTCTATTGAAAAACACTC & & \\
\hline ETA F & ACTGTAGGAGCTAGTGCATTTGT & 190 & III \\
\hline ETA R & TGGTACTTTTGTCTATCTTTTTCATCAAC & & \\
\hline SEM $F$ & CTATTAATCTTTGGGTTAATGGAGAAC & 326 & \\
\hline SEM R & TTCAGTTTCGACAGTTTTGTTGTCAT & & \\
\hline SED F & GAATTAAGTAGTACCGCGCTAAATAATATG & 492 & \\
\hline SED R & GCTGTATTTTTCCTCCGCTAAATAATATG & & \\
\hline SEG $\mathrm{F}$ & AATTATGTGAATGCTCAACCCGATC & 642 & \\
\hline SEG R & AAACTTATATGGAACSSSSGGTACTAGTTC & & \\
\hline HLA F & CTGATTACTATCCAAGAAATTCGATTG & 209 & IV \\
\hline HLA R & CTTTCCAGCCTACTTTTTTATCAGT & & \\
\hline HLB F & GTGCACTTACTGACAATAGTGC & 309 & \\
\hline HLB R & GTTGATGAGTAGCTACCTTCAGT & & \\
\hline SEH F & CAATCACATCATATGCGAAAGCAG & 376 & \\
\hline SEH R & CATCTACCCAAACATTAGCACC & & \\
\hline SEA F & GAAAAAAGTCTGAATTGCAGGGAACA & 560 & \\
\hline SEA R & CAAATAAATCGTAATTAACCGAAGGTTC & & \\
\hline SEN F & ATGAGATTGTTCTACATAGCTGCAAT & 680 & \\
\hline SEN R & AACTCTGCTCCCACTGAAC & & \\
\hline
\end{tabular}




\section{Molecular Subtyping of S. aureus Isolates}

Strains identified as $S$. aureus by PCR were submitted to PFGE using $20 \mathrm{U}$ of SmaI restriction enzyme according to Chung et al. (2000). Electrophoretic run was performed in $0.5 \times$ TBE buffer $(90 \mathrm{~m} M$ Tris, 90 $\mathrm{m} M$ boric acid, and $2 \mathrm{~m} M$ EDTA) using CHEF DRII System (Bio-Rad Laboratories, Hercules, CA), under the following conditions: $6 \mathrm{~V} / \mathrm{cm}$ for $22 \mathrm{~h}$, pulse times from 5 to $35 \mathrm{~s}$ at $14^{\circ} \mathrm{C}$. Staphylococcus aureus strain NCTC 8325 was used as the reference standard.

After being run, the gels were stained with ethidium bromide $(0.5 \mu \mathrm{g} / \mathrm{mL})$ and viewed with a UV transilluminator. Gel images were captured by Molecular ImagerGelDoc XR (Bio-Rad) and analyzed with the BioNumerics program (version 5.1; AppliedMaths, Ghent, Belgium). Clustering was performed by unweighted pair group method using arithmetic averages. Similarity of strains was estimated using the Dice correlation coefficient with $0.7 \%$ optimization and $1.0 \%$ tolerance setting. For clustering of strains, a cut-off of $80 \%$ was applied (Carriço et al., 2005). Identical PFGE profiles (100\% of similarity) were defined as a pulsotype. Gels were also analyzed by visual examination of the banding patterns to differentiate between the undistinguishable closely related strains, which were possibility related or unrelated (Tenover et al., 1995).

\section{RESULTS AND DISCUSSION}

\section{Coagulase-Positive Staphylococci}

From 10 industrialized Minas frescal cheese samples analyzed, $2(20.0 \%)$ presented CPS counts higher than the limits established as maximum legal limit $(1.0 \times$ $10^{3} \mathrm{cfu} / \mathrm{g}$ ) by Brazilian legislation (Brasil, 2001). The artisanal Minas frescal cheese was found to be potentially hazardous to public health because levels of contamination ranged from $1.2 \times 10^{3}$ to $1.5 \times 10^{7} \mathrm{cfu} / \mathrm{g}$ in $19(33.9 \%)$ of the evaluated samples. Eight (14.3\%) of them had counts higher than $10^{5} \mathrm{cfu} / \mathrm{g}$, presenting a high risk of food poisoning (Balaban and Rasooly, 2000).

The presence of CPS in cheeses made from pasteurized milk may indicate a failure in pasteurization or recontamination after pasteurization due to insufficient hygienic and sanitary practices (O'Brien et al., 2009). High counts of CPS in raw milk cheese are expected because that milk can be contaminated directly from the production environment, infected animal, or food handler (Spanu et al., 2014). Variable results have been observed by other authors in samples obtained in Brazil such as $21.0 \%$ in Bahia and $31.2 \%$ in Pernambuco (Evêncio-Luz et al., 2012) and 54.2\% in Goiás (André et al., 2008).

\section{S. aureus Identification}

Of the 19 samples of artisanal and 2 of industrialized cheeses that were positive for CPS, 29 isolates were identified as $S$. aureus by phenotypic characterization and $f e m A$ detection. All of these isolates were recovered from artisanal cheeses.

The presence of $S$. aureus in fresh raw milk cheeses is a frequent finding around the world, and the prevalence varies, for example, $2.2 \%$ (Vitale et al., 2015) and $35.0 \%$ (Bianchi et al., 2014) in Italy, 10.9\% (Jamali et al., 2015) and 45.0\% (Saadat et al., 2014) in Iran, 37.5\% in Turkey (Gücükoğlu et al., 2012), 54.2\% in Brazil (André et al., 2008), and 69.0\% in Sweden (Rosengren et al., 2010). In Switzerland, between 1996 and 2006, $63.6 \%$ of the staphylococcal food poisoning outbreaks reported were associated with cheese consumption (Baumgartner, 2008).

The handmade process in Brazil does not involve milk pasteurization, which is very important for the quality control and safety of this product. André et al. (2008) observed that the main source of contamination of the final product was the raw milk used in its production, compared with strains isolated from handlers in artisanal cheese produced in the Goiás State, Brazil.

\section{Antimicrobial Susceptibility Profile}

The resistance patterns of $S$. aureus to the tested antimicrobial agents are presented in Table 2. The tests demonstrated the susceptibility of all $S$. aureus isolates to cefoxitin, trimethoprim-sulfamethoxazole, rifampin, and erythromycin. Twelve (41.4\%) isolates were susceptible to all 9 antimicrobials tested, and 13 (44.8\%) and $3(10.3 \%)$ were resistant to penicillin and tetracycline, respectively. Intermediate susceptibility was observed in one isolate $(3.4 \%)$ for ciprofloxacin and clindamycin and in $5(17.2 \%)$ for quinupristin/dalfopristin.

In this study, 12 isolates $(41.4 \%)$ were resistant to 1 , and 2 isolates $(6.9 \%)$ were resistant to 2 antimicrobial agents. The resistance to penicillin remains the most common, as observed in other studies (André et al., 2008; Spanu et al., 2014; Jamali et al., 2015). The prevalence of resistance to $\beta$-lactam antibiotics is frequent in $S$. aureus strains obtained from milk and related products as reported by Daka et al. (2012), Hu et al. (2013), and Xu et al. (2014).

Several mechanisms are involved in $\beta$-lactam resistance, such as production of penicillinases or alteration of the target protein (Spanu et al., 2014). We did not find any isolate resistant to cefoxitin, indicating that the high resistance to penicillin observed should be as result of $\beta$-lactamase production. 
Table 2. Antimicrobial susceptibility profile of Staphylococcus aureus isolated from artisanal raw milk cheeses sold in Brazilian street fairs

\begin{tabular}{lll}
\hline Sample isolates $^{1}$ & Susceptibility profile $^{2}$ & Phenotype $^{3}$ \\
\hline Q3.2, Q12.2, Q12.3, Q15.2, Q18.1, Q18.3, Q34.3, Q35.2, Q35.3, Q35.4, Q44, Q45 & SSSSSSSSS $^{3}$ & A \\
Q9.2, Q9.3, Q14, Q15.3, Q24.3, Q36, Q46, Q49, Q56 & RSSSSSSS & SSSSSSSIS \\
Q34.2, Q35.1 & SSSSSRSSS & D \\
Q3.1 & RSSSSSSI & RSSSRSS \\
Q17 & RSSSSSIS & F \\
Q27 & RSSSISSIS & G \\
Q24.2 & RSSSSRSSS \\
Q11 & & H \\
Q54 & \\
${ }^{1}$ Q $=$ raw milk cheese. & \\
${ }^{2}$ S = susceptible; $R=$ resistant; I = intermediate. & \\
${ }^{3}$ Sequence of antimicrobials tested: penicillin, cefoxitin, trimethoprim/sulfamethoxazole, rifampim, ciprofloxacin, tetracycline, erytromycin, qui- \\
nupristin/dalfopristin, clindamycin.
\end{tabular}

Tetracycline resistance observed in this study (10.3\%) was also found in Italy by Spanu et al. (2014) in strains isolated from cheese (10.6\%). Tetracycline is used in intensive livestock production, which may explain the resistance observed in the literature in bacteria obtained from animal products (Schneider et al., 2009; Lee et al., 2014).

According to the patterns generated by the antimicrobial susceptibility tests, the 29 isolates were grouped into 9 distinct profiles, A to I (Table 2). Profile A grouped 13 isolates (44.8\%), and profile B grouped 9 $(31.0 \%)$.

\section{Detection of Virulence Genes}

Staphylococcus aureus groups are characterized by different virulence factors and by large variations in the presence of these virulence genes (Aydin et al., 2011). In this study, the presence of tst, eta, and etb genes was not found in the isolates. The hla gene was found in all isolates, and $h l b$ gene was found in $14(48.3 \%)$ of them (Table 3). Silva et al. (2012) also found $100.0 \%$ hemolytic activity among $S$. aureus isolated from bovine mastitis and most of them presented co-production of toxins.

According to Lo et al. (2011), the cytolysin production, including hemolysins, determines the pathogenicity of several bacterial agents and is associated with the pathogenesis of diseases caused by $S$. aureus. The hemolysins can be produced by the most $S$. aureus isolates (Burnside et al., 2010).

The synergistic effect between $\alpha$ and $\beta$ hemolysins is recognized as a determinant of the severity of $S$. aureus diseases, particularly bovine mastitis, with great ability of the pathogen to persist in the mammary gland, which may contaminate the milk and milk products (Aarestrup et al., 1999). The Hlb is characteristic of isolates obtained from bovine mammary gland; therefore, the findings suggest the probable source of cheeses contamination evaluated in this study.

From 29 S. aureus isolates, $13(44.8 \%)$ presented genes coding for enterotoxins. The seh gene was the most frequently detected $(\mathrm{n}=11,37.9 \%)$, followed by the seo gene $(\mathrm{n}=3 ; 10.3 \%)$, seg, sem, sen genes $(\mathrm{n}=2$; $6.9 \%)$, and sec, sei genes $(\mathrm{n}=1 ; 3.4 \%)$. In one isolate (3.4\%), 4 genes coding for SEG and SE $l \mathrm{M}, \mathrm{N}$, and O were detected. In another isolate (3.4\%), 6 genes were present (staphylococcal enterotoxins C, G, I and SEl $\mathrm{M}, \mathrm{N}, \mathrm{O})$. Both the isolates were obtained from the same artisanal raw milk cheese (Table 3 ).

The identification of new staphylococcal enterotoxins and $\mathrm{SE} l$ greatly increases the frequency of enterotoxigenic $S$. aureus isolates, which suggests an improvement on pathogenic potential of this bacteria (Bianchi et al., 2014). Among the staphylococcal enterotoxins, SEH has been responsible for staphylococcal food poi-

Table 3. Virulence genes detected in Staphylococcus aureus isolated from artisanal raw milk cheeses sold in Brazilian street fairs

\begin{tabular}{ll}
\hline Sample isolates & Virulence genes \\
\hline Q3.1, Q3.2, Q9.2, Q9.3, Q15.2, Q17, Q27, Q34.3, Q35.1, Q35.4, Q36, Q49 & $h l a+h l b$ \\
Q11, Q45 & $h l a+h l b+$ seh \\
Q12.3, Q14, Q15.3, Q18.1, Q34.2, Q35.2, Q35.3, Q56.2 & $h l a+$ seh \\
Q24.2 & $h l a+$ seg + sem + sen + seo \\
Q24.3 & $h l a+$ sec + seg + se $i+$ sem + sen + seo \\
Q46 & $h l a+$ seh + seo \\
Q12.2, Q18.3, Q44, Q54 & $h l a$ \\
\hline
\end{tabular}


soning involving milk products (Jørgensen et al., 2005; Ostyn et al., 2010). Ikeda et al. (2005) described an outbreak due to the consumption of reconstituted milk, which was contaminated with enterotoxigenic $S$. aureus producing SEA and SEH. Another outbreak was attributed to SEH produced by $S$. aureus in mashed potatoes made with raw milk (Jørgensen et al., 2005).

The SEH has been described as the most prevalent staphylococcal enterotoxin in bovine milk. Liu et al. (2014), who analyzed 116 isolates from bovine mastitis, detected the seh gene in $36.3 \%$ and sec gene in $3.4 \%$ isolates. This is similar to the results obtained in the present study, and reinforces the possible source of cheese contamination. Bianchi et al. (2014) evaluating milk products found genes sea, sed, and sec in 23.1, 47.0 , and $12.9 \%$ of the isolates, respectively, as well as the genes seg, seh, sei, sej, sep, and ser in 33.3, 4.7, 34.5, $46.7,1.17$, and $52.5 \%$, respectively.

Several studies focused on the detection of genes coding classical staphylococcal enterotoxins (SEA-SEE). In those studies, the major prevalence was observed for the sea gene, although at low percentages such as $12.8 \%$ (Spanu et al., 2014), 5.0\% (Saadat et al., 2014), 4.8\% (Gücükoğlu et al., 2012), 2.2\% (Vitale et al., 2015), and $1.6 \%$ (Ertas et al., 2010). Our study expanded the investigation for 7 more staphylococcal enterotoxins or $\mathrm{SE} l(\mathrm{G}, \mathrm{H}, \mathrm{I}, \mathrm{J}, \mathrm{M}, \mathrm{N}, \mathrm{O})$, and we observed that only sec gene among the classical staphylococcal enterotoxins was detected in $3.4 \%$ of the cheese samples. This fact demonstrates the importance of searching for other staphylococcal enterotoxins, especially in $S$. aureus obtained from food samples.

The presence of enterotoxins in milk products is considered a potential risk to public health. Several factors such as processing failures, inadequate refrigeration, improper hygienic practices, and contamination after processing are associated with $S$. aureus multiplication and enterotoxin production (Saadat et al., 2014). Therefore, the establishment and implementation of safety regulations is essential to prevent staphylococcal food poisoning.

\section{Molecular Subtyping of S. aureus}

The comparison of the 29 S. aureus isolated during the study were performed by PFGE. The isolates were assigned to 18 pulsotypes and grouped into 5 clusters (each cluster grouped 2 or more isolates with $\geq 80 \%$ of similarity; Figure 1). Cluster 1 grouped 20 isolates obtained from 13 different raw milk cheese samples. The other 4 clusters grouped 2 isolates each, and one isolate was not related to any cluster. This shows high genetic similarity among the isolates. This similarity can be explained by a possible sale of products from the same supplier in different street fairs. André et al. (2008) and Tondo et al. (2000) found more diversity among isolates obtained from dairy products in the Middle West and Southern Brazil.

We observed that some samples (Q3, Q9, Q15, Q18, Q24, Q35) presented more than one genetically distinct isolate, and genetically identical isolates $(100 \%$ similarity) were obtained from different samples. As demonstrated in Figure 1, one sample (Q35) contained 4 isolates that, although grouped in the same cluster, presented distinct pulsotypes, different susceptibility, or different virulence profile. This observation shows that during the cheese production chain, contamination could occur from several sources in the milk and cheese production environment, as well as from the animal or food handler (Spanu et al., 2014). This could be minimized if hygienic processing was intensified to prevent cross-contamination among the potential sources of food contamination.

All 11 S. aureus isolates harboring the seh gene, obtained from 10 different samples, were grouped in cluster 1, which demonstrates high similarity among these isolates, although they were isolated from samples produced in distinct places at different times. The genes coding for other staphylococcal enterotoxins (C, $\mathrm{G}, \mathrm{I}, \mathrm{M}, \mathrm{N}, \mathrm{O}$ ), detected in 2 isolates obtained from the same sample, were grouped in cluster 3 with $92.7 \%$ similarity. It has been demonstrated that the seh gene is the most prevalent in $S$. aureus isolates from bovine mastitis (Liu et al., 2014). The present study found the seh gene in $37.9 \%$ of the $S$. aureus isolated from raw milk cheeses, which indicates the most probable source of the bacteria for the product was the bovine milk.

The association of distinct molecular typing techniques is helpful to improve the knowledge about the dynamics of infections caused by $S$. aureus. The combination of PFGE with PCR is an important tool for epidemiological diagnosis as well as to understand the patterns of pathogen transmission and sources of possible food contamination (Said et al., 2010).

\section{CONCLUSIONS}

The presence of $S$. aureus above the limit established by law and at levels compatible with the production of enterotoxins in artisanal raw milk cheeses points to the potential risk to public health. Consumption of this product is still widespread in Brazil; therefore, an effective reduction of contamination levels could be achieved by improving sanitation and hygiene procedures. The consumption of artisanal raw milk cheese should be considered a potential risk of foodborne disease because genes coding for enterotoxin production were detected. The identification of enterotoxins, other than the classic 
Dice (Opt:0.70\%) $($ Tol 1.0\%-1.0\%) $(H>0.0 \% \mathrm{~S}>0.0 \%)[0.0 \%-100.0 \%]$

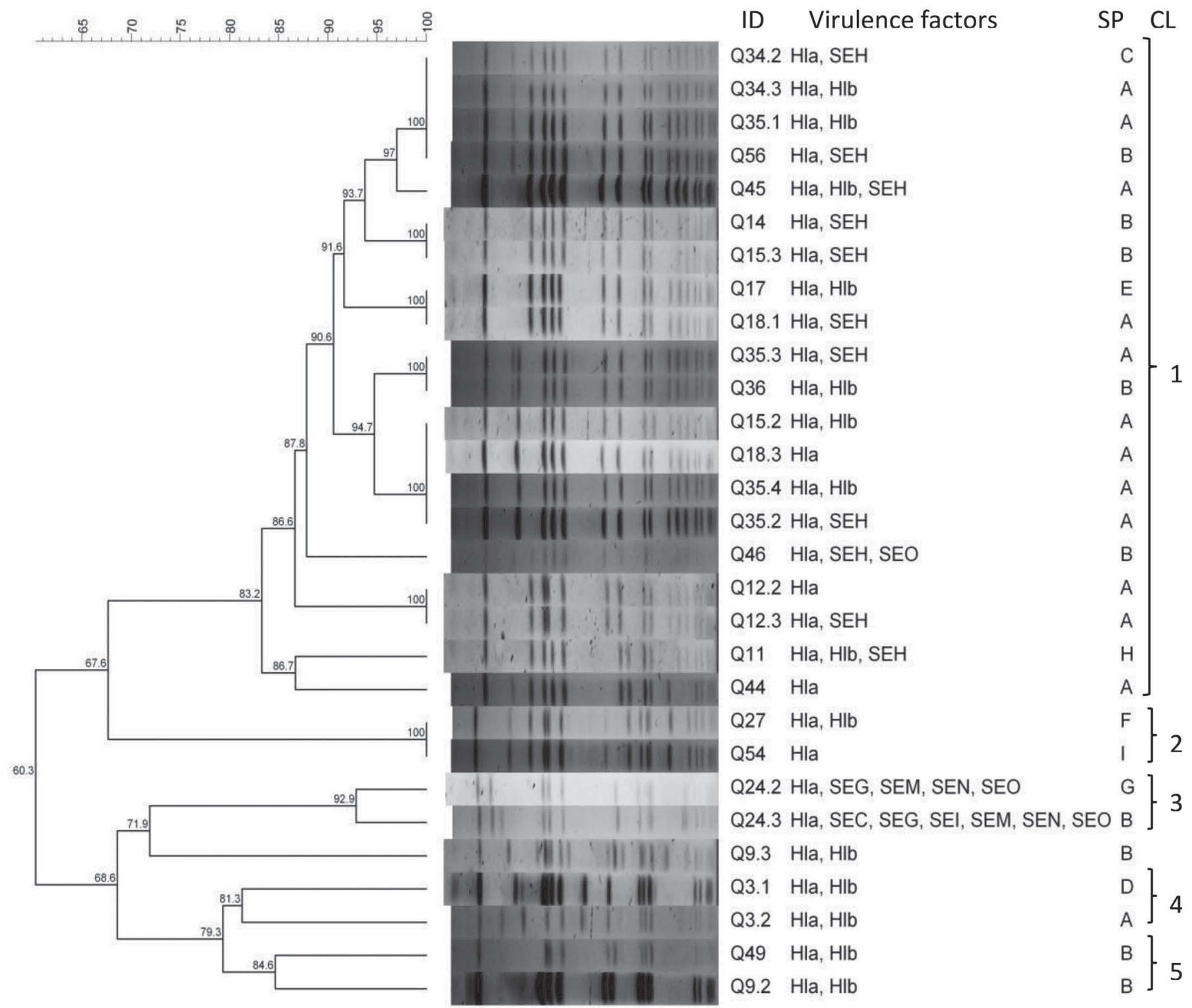

Figure 1. Clonal relationships, virulence, and susceptibility profile of Staphylococcus aureus isolated from raw milk cheese, established with SmaI pulsed-field gel electrophoresis analysis. ID = sample identification; $\mathrm{SP}=$ susceptibility profile; $\mathrm{CL}=$ cluster; Hla $=$ hemolysin A; Hlb $=$ hemolysin B; SE = staphylococcal enterotoxin.

ones, highlights the importance of expanding research to detect these virulence factors for food safety assurance. The combination of genotypic and phenotypic methods used helps to trace the origin of the strains. The virulence pattern observed in most of the isolates led us to conclude that the contamination of traditional and artisanal raw milk cheese with $S$. aureus, despite the handmade production, is probably of animal origin. Therefore, milk pasteurization, as recommended by the supervisory agencies, should solve most of the problem.

\section{ACKNOWLEDGMENTS}

This research was funded by Coordenação de Aperfeiçoamento de Pessoal de Nível Superior (CAPES).

\section{REFERENCES}

Aarestrup, F. M., H. D. Larsen, N. H. Eriksen, C. S. Elsberg, and N. E. Jensen. 1999. Frequency of alpha- and beta-haemolysin in Staphylococcus aureus of bovine and human origin. A comparison between pheno- and genotype and variation in phenotypic expression. AP- 
MIS 107:425-430. http://dx.doi.org/10.1111/j.1699-0463.1999. tb01576.x.

Aires-de-Sousa, M., C. E. Parente, O. Vieira-Da-Motta, I. C. Bonna, D. A. Silva, and H. de Lencastre. 2007. Characterization of Staphylococcus aureus isolates from buffalo, bovine, ovine, and caprine milk samples collected in Rio de Janeiro State, Brazil. Appl. Environ. Microbiol. 73:3845-3849. http://dx.doi.org/10.1128/ AEM.00019-07.

André, M. C. D. P. B., M. R. H. Campos, L. J. Borges, A. Kipnis, F. C. Pimenta, and A. B. Serafini. 2008. Comparison of Staphylococcus aureus isolates from food handlers, raw bovine milk and Minas Frescal cheese by antibiogram and pulsed-field gel electrophoresis following SmaI digestion. Food Contr. 19:200-207. http://dx.doi. org/10.1016/j.foodcont.2007.03.010.

ANVISA (Agência Nacional de Vigilância Sanitária). 2015. Vigilância Epidemiológica das Doenças Transmitidas por Alimentos-VEDTA. Accessed Nov. 14, 2015. http://u.saude.gov.br/images/ pdf/2015/novembro/09/Apresenta----o-dados-gerais-DTA-2015. pdf.

Araújo, J. M., M. Galdino, and S. M. Amaral. 2011. MRSA de origem comunitária. Resid. Ped. 1:39-40.

Argudin, M. A., M. C. Mendoza, and M. R. Rodicio. 2010. Food poisoning and Staphylococcus aureus enterotoxins. Toxins (Basel) 2:1751-1773. http://dx.doi.org/10.3390/toxins2071751.

Aydin, A., M. Sudagidan, and K. Muratoglu. 2011. Prevalence of staphylococcal enterotoxins, toxin genes and genetic-relatedness of foodborne Staphylococcus aureus strains isolated in the Marmara Region of Turkey. Int. J. Food Microbiol. 148:99-106. http:// dx.doi.org/10.1016/j.ijfoodmicro.2011.05.007.

Balaban, N., and A. Rasooly. 2000. Staphylococcal enterotoxins. Int. J. Food Microbiol. 61:1-10. http://dx.doi.org/10.1016/S01681605(00)00377-9.

Baumgartner, A. 2008. Outbreaks with microbial contaminated foodstuffs in Switzerland 1994-2006. Bull. Swiss Federal Off. Public Health 32:562-568.

Bennett, R. W., and G. A. Lancette. 2001. Staphylococcus aureus. Chapter 12 in Bacteriological Analytical Methods. US Food and Drug Administration. Accessed Feb. 22, 2012. http://www.fda. gov/Food/FoodScienceResearch/LaboratoryMethods/ucm071429. htm.

Bianchi, D. M., S. Gallina, A. Bellio, F. Chiesa, T. Civera, and L. de Castelli. 2014. Enterotoxin gene profiles of Staphylococcus aureus isolated from milk and dairy products in Italy. Lett. Appl. Microbiol. 58:190-196. http://dx.doi.org/10.1111/lam.12182.

Brasil. 2001. Ministério da Saúde. Resolução $\mathrm{n}^{\mathrm{o}}$ 12, de 02 de janeiro de 2001. Regulamento Técnico sobre Padrões Microbiológicos para Alimentos. Diário Oficial da República Federativa do Brasil, Brasília, DF.

Burnside, K., A. M. Lembo, M. de Los Reyes, A. Iljuk, N. T. Binhtran, J. E. Connelly, W. J. Lin, B. Z. Schmidt, A. R. Richardson, F. C. Fang, W. A. Tao, and L. Rajagopal. 2010. Regulation of hemolysin expression and virulence of Staphylococcus aureus by a serine/ threonine kinase and phosphatase. PLoS ONE 5:e11071. http:// dx.doi.org/10.1371/journal.pone.0011071.

Carriço, J. A., F. R. Pinto, C. Simas, S. Nunes, N. G. Sousa, N. Frazao, H. de Lencastre, and J. S. Almeida. 2005. Assessment of band-based similarity coefficients for automatic type and subtype classification of microbial isolates analyzed by pulsed-field gel electrophoresis. J. Clin. Microbiol. 43:5483-5490. http://dx.doi. org/10.1128/JCM.43.11.5483-5490.2005.

Cha, J., S. B. Vakulenko, and S. Mobashery. 2007. Characterization of the beta-lactam antibiotic sensor domain of the MecR1 signal sensor/transducer protein from Methicillin-Resistant Staphylococcus aureus. Biochemistry 46:7822-7831.

Chalita, M. A. N., R. O. P. Silva, R. H. V. Petti, and C. R. L. Silva 2009. Algumas considerações sobre a fragilidade das concepções de qualidade no mercado de queijos no Brasil. Inf. Econ. 39:77-88.

Chung, M., H. de Lencastre, P. Matthews, A. Tomasz, I. Adamsson, M. Aires De Sousa, and T. Camou. 2000. Molecular typing of methicillin-resistant Staphylococcus aureus by pulsed-field gel electrophoresis: Comparison of results obtained in a multilaboratory effort using identical protocols and MRSA strains. Microb. Drug Resist. 6:189-198.

CLSI (Clinical and Laboratory Standards Institute). 2015. Performance Standards for Antimicrobial Susceptibility Testing, Twenty-fifth Informational Supplement. CLSI document M100- S25. Wayne, PA.

Daka, D., G. S. Solomon, and D. Yihdego. 2012. Antibiotic-resistance Staphylococcus aureus isolated from cow's milk in the Hawassa area, South Ethiopia. Ann. Clin. Microbiol. Antimicrob. 11:26. http://dx.doi.org/10.1186/1476-0711-11-26

Delsol, A. A., D. E. Halfhide, M. C. Bagnall, L. P. Randall, V. I. Enne, M. J. Woodward, and J. M. Roe. 2010. Persistence of a wild type Escherichia coli and its multiple antibiotic-resistant (MAR) derivatives in the abattoir and on chilled pig carcasses. Int. J. Food Microbiol. 140:249-253. http://dx.doi.org/10.1016/j. ijfoodmicro.2010.03.023.

Dorigon, C. 2010. O Mercado Informal dos Produtos Coloniais da Região Oeste de Santa Catarina. V ENEC - Encontro Nacional de Estudos do Consumo I Encontro Luso-Brasileiro de Estudos do Consumo Tendências e ideologias do consumo no mundo contemporâneo. Accessed Oct. 10, 2014. http://estudosdoconsumo.com. br/wpcontent/uploads/2010/09/1.3-_Clovis_Dorigon1.pdf.

ECDC (European Centre for Disease Prevention and Control). 2015. The European Union summary report on trends and sources of zoonoses, zoonotic agents and food-borne outbreaks in 2013. EFSA J. 13:162.

Ertas, N., Z. Gonulalan, Y. Yildirim, and E. Kum. 2010. Detection of Staphylococcus aureus enterotoxins in sheep cheese and dairy desserts by multiplex PCR technique. Int. J. Food Microbiol. 142:7477. http://dx.doi.org/10.1016/j.ijfoodmicro.2010.06.002.

Evêncio-Luz, L., J. V. Lima-Filho, and J. Evêncio-Neto. 2012. Occurrence of Salmonella sp. and coagulase-positive Staphylococci in raw eggs and coalho cheese: Comparative study between two cities of Brazil's northeast. Braz. J. Microbiol. 43:1463-1466.

Gücükoğlu, A., T. O. Kevenk, T. Uyanik, Ö. Çadirci, G. Terzi, and M. Alisarli. 2012. Detection of enterotoxigenic Staphylococcus aureus in raw milk and dairy products by multiplex PCR. J. Food Sci. 77:M620-M623. http://dx.doi.org/10.1111/j.17503841.2012.02954.x

Holtfreter, S., D. Grumann, M. Schmudde, H. T. T. Nguyen, P. Eichler, B. Strommenger, K. Kopron, J. Kolata, S. Giedrys-Kalemba, I. Steinmetz, W. Witte, and B. M. Bröker. 2007. Clonal distribution of superantigen genes in clinical Staphylococcus aureus isolates. J. Clin. Microbiol. 45:2669-2680. http://dx.doi.org/10.1128/ JCM.00204-07.

Hu, S. K., S. Y. Liu, W. F. Hu, T. L. Zheng, and J. G. Xu. 2013. Molecular biological characteristics of Staphylococcus aureus isolated from food. Eur. Food Res. Technol. 236:285-291. http://dx.doi. org/10.1007/s00217-012-1887-4.

Ikeda, T., N. Tamate, K. Yamaguchi, and S. Makino. 2005. Mass outbreak of food poisoning disease caused by small amounts of staphylococcal enterotoxins A and H. Appl. Environ. Microbiol. 71:27932795. http://dx.doi.org/10.1128/AEM.71.5.2793-2795.2005.

Jamali, H., M. Paydar, B. Radmehr, S. Ismail, and A. Dadrasnia. 2015. Prevalence and antimicrobial resistance of Staphylococcus aureus isolated from raw milk and dairy products. Food Contr. 54:383-388. http://dx.doi.org/10.1016/j.foodcont.2015.02.013.

Jarraud, S., C. Mougel, J. Thioulouse, G. Lina, H. Meugnier, F. Forey, X. Nesme, J. Etienne, and F. Vandenesch. 2002. Relationships between Staphylococcus aureus genetic background, virulence factors, agr groups (alleles), and human disease. Infect. Immun. 70:631641. http://dx.doi.org/10.1128/IAI.70.2.631-641.2002.

Jørgensen, H. J., T. Mørk, D. A. Caugant, A. Kearns, and L. M. Rørvik. 2005. Genetic variation among Staphylococcus aureus strains from Norwegian bulk milk. Appl. Environ. Microbiol. 71:83528361. http://dx.doi.org/10.1128/AEM.71.12.8352-8361.2005.

Lee, M., E. Shin, and Y. Lee. 2014. Antimicrobial resistance and integron profiles in multidrug-resistant Escherichia coli isolates from pigs. Foodborne Pathog. Dis. 11:988-997. http://dx.doi. org/10.1089/fpd.2014.1795. 
Liu, Y., W. Chen, T. Ali, R. Alkasir, J. Yin, G. Liu, and B. Han. 2014. Staphylococcal enterotoxin $\mathrm{H}$ induced apoptosis of bovine mammary epithelial cells in vitro. Toxins (Basel) 6:3552-3567. http:// dx.doi.org/10.3390/toxins6123552.

Lo, C. W., Y. K. Lai, Y. T. Liu, R. L. Gallo, and C. M. Huang. 2011. Staphylococcus aureus hijacks a skin commensal to intensify its virulence: Immunization targeting $\beta$-hemolysin and camp factor. J. Invest. Dermatol. 131:401-409. http://dx.doi.org/10.1038/ jid.2010.319.

Mehrotra, M., G. Wang, and W. M. Johnson. 2000. Multiplex PCR for detection of genes for Staphylococcus aureus enterotoxins, exfoliative toxins, toxic shock syndrome toxin 1 , and methicillin resistance. J. Clin. Microbiol. 38:1032-1035.

O'Brien, M., K. Hunt, S. McSweeney, and K. Jordan. 2009. Occurrence of foodborne pathogens in Irish farmhouse cheese. Food Microbiol. 26:910-914. http://dx.doi.org/10.1016/j.fm.2009.06.009.

Ostyn, A., M. L. De Buyser, F. Guillier, J. Groult, B. Felix, S. Salah, G. Delmas, and J. A. Hennekinne. 2010. First evidence of a food poisoning outbreak due to staphylococcal enterotoxin type E, France, 2009. Euro Surveill. 15:19528.

Rosengren, A., A. Fabricius, B. Guss, S. Sylvén, and R. Lindqvist. 2010. Occurrence of foodborne pathogens and characterization of Staphylococcus aureus in cheese produced on farm-dairies. Int. J. Food Microbiol. 144:263-269. http://dx.doi.org/10.1016/j. ijfoodmicro.2010.10.004.

Saadat, Y. R., A. A. I. Fooladi, R. Shapouri, M. M. Hosseini, and Z. D. Khiabani. 2014. Prevalence of enterotoxigenic Staphylococcus aureus, in organic milk and cheese in Tabriz, Iran. Iran. J. Microbiol. 6:345-349.

Said, K. B., J. Ismail, J. Campbell, M. R. Mulvey, A. Bourgault, S. Messier, and X. Zhao. 2010. Regional profiling for determination of genotype diversity of mastitis-specific Staphylococcus aureus lineage in Canada by use of clumping factor, a pulsed-field gel electrophoresis, and spa typing. J. Clin. Microbiol. 48:375-386. http:// dx.doi.org/10.1128/JCM.01768-09.

Schneider, R. N., A. Nadvorny, and V. Schmidt. 2009. Perfil de resistência antimicrobiana de isolados de Escherichia coli obtidos de águas superficiais e subterrâneas, em área de produção de suínos. Biotemas. 22:11-17.

Silva, E. R., T. R. M. Silva, A. M. G. Pereira, A. C. Machado, and K. R. Santoro. 2012. Produção de hemolisinas por Staphylococcus aureus isolados de casos de mastite bovina subclínica. Acta Vet. Brasilica 6:118-123.

Spanu, V., C. Scarano, F. Cossu, C. Spanu, and E. P. L. de Santis. 2014. Antibiotic resistance traits and molecular subtyping of Staphylococcus aureus isolated from raw sheep milk cheese. J. Food Sci 79:M2066-M2071. http://dx.doi.org/10.1111/1750-3841.12590.

Tenover, F. C., R. D. Arbeit, R. V. Goering, P. A. Mickelsen, B. A. Murray, D. H. Persing, and B. Swaminathan. 1995. Interpreting chromosomal DNA restriction patterns produced by pulsed-field gel electrophoresis: criteria for bacterial strain typing. J. Clin. Microbiol. 33:2233-2239.

Tondo, E. C., M. C. Guimarães, J. A. Henriques, and M. A. Ayub. 2000. Assessing and analysing contamination of a dairy products processing plant by Staphylococcus aureus using antibiotic resistance and PFGE. Can. J. Microbiol. 46:1108-1114.

Vandenesch, F., G. Lina, and T. Henry. 2012. Staphylococcus aureus hemolysins, bi-component leukocidins, and cytolytic peptides: A redundant arsenal of membrane-damaging virulence factors? Front. Cell. Infect. Microbiol. 2:12. http://dx.doi.org/10.3389/ fcimb. 2012.00012

Vitale, M., M. L. Scatassa, C. Cardamone, G. Oliveri, C. Piraino, R. Alduina, and C. Napoli. 2015. Staphylococcal food poisoning case and molecular analysis of toxin genes in Staphylococcus aureus strains isolated from food in Sicily, Italy. Foodborne Pathog. Dis. 12:21-23. http://dx.doi.org/10.1089/fpd.2014.1760.

Wallin-Carlquist, N., D. Marta, E. Borch, and P. Råadströom. 2010. Prolonged expression and production of Staphylococcus aureus enterotoxin $\mathrm{A}$ in processed pork meat. Int. J. Food Microbiol. 141:S69-S74. http://dx.doi.org/10.1016/j.ijfoodmicro.2010.03.028.

Xu, J., C. Shi, M. Song, X. Xu, P. Yang, G. Paoli, and X. Shi. 2014. Phenotypic and genotypic antimicrobial resistance traits of foodborne Staphylococcus aureus isolates from Shanghai. J. Food Sci. 79:M635-M642. http://dx.doi.org/10.1111/1750-3841.12405.

Xu, S. X., and J. K. McCormick. 2012. Staphylococcal superantigens in colonization and disease. Front. Cell. Infect. Microbiol. 2:52. http://dx.doi.org/10.3389/fcimb.2012.00052.

Zschock, M., B. Kloppert, W. Wolter, H. P. Hamann, and C. Lammler. 2005. Pattern of enterotoxin genes seg, seh, sei and sej positive Staphylococcus aureus isolated from bovine mastitis. Vet. Microbiol. 108:243-249. http://dx.doi.org/10.1016/j.vetmic.2005.02.012. 